\title{
Daughter of time: the postmodern midwife (Part 2)
}

\author{
FILHA DO TEMPO: A PARTEIRA PÓS-MODERNA (PARTE 2) \\ HIJA DEL TIEMPO: LA PARTERA POS-MODERNA (PARTE 2
}

\author{
Robbie Davis-Floyd ${ }^{1}$
}

\begin{abstract}
Any effort to make sense of the complexities of contemporary mid wifery must deal not only with biomedical and governmental power structures but also with the definitions such structures impose upon midwives and the ramifications of these definitions within and across national and cultural borders. The international definition of a midwife requires graduations from a government-recognized educational program. Those who have not are not considered midwives but are labeled traditional birth attendants. Since there are myriad local names for midwives in myriad languages, the impact of this naming at local levels can be hard to assess. But on the global scale, the ramifications of the distinction between midwives who meet the international definition and those who do not have been profound. Those who do are incorporated into the health care system. Those who do not remain outside of it, and suffer multiple forms of discrimination as a result.
\end{abstract}

\section{KEY WORDS}

Midwives, practical. Transcultural nursing. Nurse midwives.

\section{RESUMO}

Qualquer esforço para dar sentido à complexidade do processo reprodutivo na vida contemporânea se depara não só com o modelo biomédico e as estruturas governamentais de poder, mas também com as definições que tais estruturas impõem às parteiras e obstetrizes e à sua denominação, considerando-se os limites nacionais e culturais. A definição internacional de parteira demanda a formação em instituições de ensino reconhecidas pelo governo. As parteiras tradicionais não podem ser consideradas parteiras, mas são denominadas parteiras tradicionais. Há uma gama enorme de denominações para as parteiras em diversos locais, nas diversas línguas e ao longo do tempo, que torna difícil nomear este profissional. Entretanto, em escala global, pode-se reconhecer que há duas ramificações de parteira: a que está incorporada ao sistema de saúde e a que está fora dele.

\section{DESCRITORES}

Parteira leiga.

Enfermagem transcultural.

Enfermeiras obstétricas.

\section{RESUMEN}

Cualquier esfuerzo para dar sentido a la complejidad del proceso reproductivo en la vida contemporánea se depara no solamente con el modelo biomédico y las estructuras gubernamentales de poder, sino con las definiciones que estas estructuras imponen a las parteras y matronas y su denominación considerándose los límites nacionales y culturales. La definición internacional de partera demanda formación en instituciones de enseñanza reconocidas por el gobierno. Las parteras tradicionales no pueden ser consideradas parteras, pero son denominadas parteras tradicionales. Hay una gama enorme de denominaciones para las parteras, en diversos locales, en las diversas lenguas y a lo largo del tiempo, y por eso es difícil nombrar a este profesional. No obstante, en escala global se puede reconocer que hay dos ramificaciones de partera: la que está incorporada al sistema de salud y la que está fuera de él.

\section{DESCRIPTORES}

Parteras tradicionales. Enfermería transcultural. Enfermeras obstetrices.

${ }^{1}$ Robbie Davis-Floyd, PhD, a Cultural/Medical Anthropologist Specializing in the Anthropology of Reproduction, is Senior Research Fellow in the Department of Anthropology, University of Texas, Austin, USA. davis-floyd@mail.utexas.edu 


\section{THE PROFESSIONAL MIDWIFE AS POSTMODERN}

Around the world we are witnessing the emergence of a phenomenon that I call postmodern midwifery --a term aimed at capturing those aspects of contemporary midwifery practice that fall outside easy distinctions between traditional birthways, professional midwifery, and modern biomedicine. With this term, I am trying to highlight the qualities that emerge from the practice, the discourse, and the political engagement of a certain kind of contemporary midwife-one who often constructs a radical critique of unexamined conventions and univariate assumptions. Postmodern midwives as I define them are relativistic, articulate, organized, political, and highly conscious of both their cultural uniqueness and their global importance. By postmodern midwife I specifically do not mean midwives who accept without criticism either their own folk system or that of biomedicine, but rather midwives who fully understand these in a relative way, as different ways of knowing about birth, discrepant systems that often conflict but can be complementary.

Although unlike traditional midwives, professional midwives have the structural benefits conferred by government certification, access to certain technologies, and the status-conferring white coat, they still must struggle with the pressures imposed on them by the modernist and colonialist biomedical model, which defines biomedicine as structurally superior to traditional medicine, doctors as superior to midwives, and professional midwives as superior to traditional midwives. Where doctors are few and midwives predominate, professional midwives have opportunities to establish themselves as relatively autonomous practitioners and can make culturally and individually reasonable choices about how to interact with the local traditional midwives. Where doctors are many and professional midwives are clearly subordinate to them in medical hierarchies, they often find that their only route to biomedical status and respect involves rejection of, and often downright rudeness too, traditional midwives and their clients. Studies show that in some places, professional midwives trained in government-approved two-year courses and sent to rural villages work hard to get to know the village women, to give them nurturant care, and to cooperate with the local village midwives ${ }^{(1-3)}$. But in others, professional midwives adopt an attitude of arrogance and superiority, and treat the village women disrespectfully ${ }^{(4-6)}$, in effect discouraging further referrals to the hospital. It is a paradox of contemporary midwifery that while some professional midwives are working hard to help traditional midwives creatively adapt biomedicine to their native systems ${ }^{(7-10)}$, other professional midwives and most physicians are working equally hard to further marginalize or fully eliminate their traditional predecessors ${ }^{(11-15)}$.
Postmodern professional midwives as I am defining them very consciously strive not to engage in such behaviors. Those who are not considered midwives (in English) but are labeled TBA (traditional birth attendants). When they interface with TBA, they apply the same relativistic perspective to the knowledge system of the TBA as they do to the knowledge system of biomedicine. In other words, they seek to identify and support efficacious aspects of the traditional birthing system, and, respectfully and sensitively, to change harmful practices. I could cite hundreds of examples of professional postmodern midwives. But for the sake of space and simplicity, I will confine myself to three studies recently published in a special issue of Medical Anthropology entitled Daughters of Time: The Shifting Identities of Contemporary Midwives, which I co edited ${ }^{(16)}$ on midwives in Mexico, Japan, and the Netherlands who fully exemplify my profile of the professional postmodern midwife. Here I will briefly summarize these descriptions.

\section{POSTMODERN PROFESSIONAL MIDWIVES IN MEXICO}

My ethnographic research in Mexico ${ }^{(10,17)}$ documents the emergence of an entirely new kind of midwife, the thoroughly postmodern partera professional. These women of diverse sociocultural backgrounds initially sought training from American direct-entry midwives in the independent out-ofhospital midwifery model; since then they have been reformulating that model for Mexico. Through their own practices, intensive liaison work with traditional midwives, and organizing national midwifery conferences and meetings, they are creating midwifery as both an emerging profession and social movement in Mexico. Some of them operate outside the medical system while others are carving a niche within it. These 50 or so women face a long struggle to define their identities, legalize their practices, and generate a sustainable space within the emergent Mexican technocracy. To their intense dismay, this struggle must take place within the context of the disappearance of Mexico's traditional midwives, who are vanishing at a rapid rate (in the 1970s, traditional midwives attended over $40 \%$ of Mexican births; today that figure is below $15 \%$ and the majority are over 65 years of age). Mexico's new professional midwives live in constant tension between their desire to preserve traditional midwifery and the need to create a sustainable form of professional midwifery. They cope with this tension by adding to their professional knowledge base many traditional birthing techniques (such as the use of herbs and of the rebozo (shawl) to shift the baby's position). And they help traditional midwives as best they can through foundations, joint conferences, skills-sharing workshops, and government advocacy.

This effort to respectfully combine professional and traditional knowledge systems is particularly visible at the CASA School for Professional Midwives in San Miguel 
de Allende, where students undergo a professional threeyear training program that combines didactic classroom work, clinical work in the CASA hospital, and five threeweek apprenticeships with traditional midwives in small and remote rural villages ${ }^{(10)}$. These apprenticeships not only allow the professional students to incorporate traditional techniques into their practices, but also prevent them from developing the attitude of arrogance and superiority that many professional midwives around the world exhibit toward traditional midwives. Living in the homes of the traditional midwives, helping with their daily routines, and observing their forms of care instill an attitude of deep respect and admiration for these elder midwives in the younger professional midwifery students, and a strong desire to follow in their footsteps while making the path they traced viable in the postmodern technocracy.

\section{POSTMODERN PROFESSIONAL MIDWIVES IN JAPAN}

Japanese anthropologist ${ }^{(18)}$ demonstrates how the shift in Japan from agriculture to industrial production to the contemporary service and information economy (which I call the technocracy) has been mirrored by a shift from birth at home attended by traditional midwives, to hospital births attended primarily by professional midwives, to the emergence of new midwives who are beginning to offer Japanese female consumers a plethora of options for childbirth. In Japan's premodern period from the 1880 s to the 1950s, licensed independent midwives exerted a strong influence in society as they organized themselves on both local and national levels. Japan's modernization period took place after WWII from the 1950s to the 1970s as Japan experienced rapid economic growth. In those days professional midwives went into hospitals to produce babies just as workers went into factories to produce goods. But since the 1980s, with the advent of the natural childbirth movement, a new type of postmodern Japanese midwife has emerged.

The midwives who have been playing a prominent role in this natural childbirth movement are different from either of the two previous figures: they practice independently but cooperate with and learn from each other. Many of them have worked in hospitals for years but have passed in their thinking about birth beyond the limitations of the medical model and have come out on the other side. They pursue their own midwifery model of care and are developing new identities. Some have their own maternity homes or birth houses (known in the US as freestanding birth centers) and others work in hospitals trying to introduce a better way within a medical setting. They are mediators, crossing the boundaries between obstetric care and alternative care, home and hospital, modern and traditional, local and international, and thereby increasing options women. Ironically, these options include the re-incorporation of elements associated with traditional birth, such as out-ofhospital birth and the use of upright positions. The primary reason these Japanese midwives give for leaving hospital practice is the damage to mother and baby they observe to be caused by the application of routine technological interventions to the process of parturition. Their personal evolutions through hospital practice to attending births in birth cen-ters and homes contradict modernist evolutionary notions that defined the movement of birth from home to hospital as medical progress.

\section{POSTMODERN PROFESSIONAL MIDWIVES IN THE NETHERLANDS}

While other modernizing nations moved birth to the hospital and brought midwives under the authority of physicians, an autonomous profession of midwifery and home based maternity care were preserved in the Netherlands, where around thirty percent of births still take place at home. Many regard the Dutch midwifery system as one of the best in the world. But sociologist ${ }^{(19-20)}$ shows that the same system touted by outsiders as a postmodern vanguard is regarded by some within the Netherlands as a premodern vestige from the past. As the world around them has changed, Dutch midwives have had to find new strategies to protect their profession and the right of Dutch women to choose their place of birth. DeVries examines the transformation of premodern midwifery into postmodern midwifery in the Netherlands. Noting that Dutch women were among the last in Europe to enter the workplace, DeVries links the historical Dutch emphasis on home and family to the contemporary retention of autonomous midwifery and home birth. He shows that as more and more Dutch women began to enter the workplace, home birth began a rapid decline. But by the early 1990s the Dutch midwives and mothers, newly aware that they were losing something precious, embarked on a campaign to create a postmodern social movement around preserving home birth. In this endeavor they found support in scientific evidence, to which the Dutch government paid close attention. Thus the Dutch case remains one of the premier examples of a thriving postmodern midwifery system that effectively incorporates autonomous midwifery care within the national health care system. The Dutch case demonstrates a primary value of postmodernism in health care: its relativistic approach allows each system to be judged on its own merits relative to the scientific evidence and to other systems, forestalling the univariate modernist view of biomedicine as superior.

\section{PROFESSIONAL VS. TRADITIONAL MIDWIVES: THE RAMIFICATIONS OF DEFINITION}

Any effort to make sense of the complexities of contemporary midwifery must deal not only with biomedical and governmental power structures but also with the definitions such structures impose upon midwives and the ramifications of these definitions within and across 
national and cultural borders. The international definition of a midwife requires graduations from a governmentrecognized educational program. Since there are myriad local names for midwives in myriad languages (and many modes of birth assistance that occur but are not performed by named folk specialists), the impact of this naming at local levels can be hard to assess ${ }^{(21-23)}$. But on the global scale, the ramifications of the distinction between midwives who meet the international definition and those who do not have been profound. Those who do are incorporated into the health care system (usually below doctors in the medical hierarchy and above nurses). Those who do not remain outside of it, and suffer multiple forms of discrimination as a result.

Many social scientists studying contemporary midwifery find the arbitrary distinction between TBA and midwives to be highly problematic in terms of its cultural effects. From a social science perspective, a governmentapproved midwifery training does not necessarily produce a midwife-it may produce a mini-doctor instead. Thus social scientists tend to define a midwife not only in terms of their attendance at a birth but also in terms of their social and community roles. In other words, for most social scientists, a midwife can be a practitioner who meets the international definition and/or one who is recognized as such by their community.

In general, social scientists do not assume that the role or the practice of professional midwives according to the international definition is any more important to the welfare of women and children than the role of the practitioners officially classified as TBA. Every social scientist who studies contemporary midwifery (including social scientists who are also midwives) is impressed by the ongoing contributions of TBA and concerned by the colonialist and biomedical limitations of professional midwives. (Social scientists who study midwives also support midwifery in general, as we know midwives to be the most suited practitioners for all but high-risk maternity care.) Traditional midwives have already vanished or are vanishing at a rapid rate in many parts of the world. Yet those who remain, from the Indian dai to the Mexican partera tradicional, are providing vital services to the populations they serve, both rural and urban, and preserving knowledge systems that contain much that is of value and relevance in the postmodern world.

Defining traditional midwives as TBA is a powerful statement that their knowledge does not count in the global system. And indeed in some cases their practices have been shown to be scientifically unsound, just as the practices of many professional midwives and many physicians have also been shown. The point is not to romanticize traditional midwives, but to approach them with the same informed relativism that postmodern professional midwives apply to biomedicine. A relativistic, postmodern perspective reveals that the same traditional midwife who uses cow dung on the umbilicus or tells a mother that her colostrum is bad for her baby can often skillfully and successfully attend births that would confound professional midwives accustomed to obstetrical backup. The same postmodern perspective reveals that professional midwives with years of government-approved training may withhold food and drink from laboring women and force them to deliver flat on their backs. Indeed, the surest marker that traditional midwives have had contact with professional midwives and government-sponsored trainings is that they suddenly begin to demand that their clients deliver in that most unscientific of positions. There is nothing postmodern about the willful eradication of traditional healing and birth systems, and everything postmodern about their preservation and their combination with science-based professional midwifery knowledge. This is a challenge faced by all postmodern midwives, whether professional, or traditional, or an elision of both.

As I hope I have made clear, postmodern professional midwives in my definition are culturally sensitive and competent, work respectfully and cooperatively with traditional midwives and, like the CASA students, include traditional practices in their repertoire. And postmodern traditional midwives gain exposure to both biomedical and professional midwifery information and techniques and selectively incorporate these into their practice, learning as they go. Thus the line between the professional and the traditional midwife is becoming increasingly blurry. This fact affects the ongoing viability of the international definition of a midwife and the ultimate goal of all midwives-the welfare of mothers and babies.

\section{CONCLUSION}

Postmodern midwives, for all their value, often find themselves living in a constant state of stress, lobbying legislatures for the right to exist, struggling to balance conflicting ideologies and knowledge systems, and arguing with each other about appropriate standards for education and practice. In developed and developing countries alike, the tensions between biomedical, traditional, and alternative knowledge systems permeate professional midwifery training and praxis and generate conflicts between midwifery educators, between educators and students, and among practicing midwives and those who regulate them. The professional midwives of the indus-trialized North are accelerating their long struggle for autonomy even as traditional midwives in the less affluent countries of the South continue to lose the autonomy they formerly held. In short, today nothing is easy about being a midwife of any type. Yet motivated by a shared desire to offer viable longterm options to biomedical birth, these daughters of time and tradition continue their struggle, with varying degrees of success, but always with the necessary determination to make sure that midwives, with all their limitations and all their power, remain available to care for the mothers and babies of the contemporary world. 


\section{REFERENCES}

1. Chen PCY. Incorporating the traditional birth attendant in the health team: the Malaysian example. Trop Geogr Med. 1977;29(2):192-6.

2. Kroeger M. Final Consultant Report. CHN 3 Project. Java, Indonesia: Provincial Department of Health Central Java; 1996.

3. Kwast B. Midwives role in safe motherhood. J Nurse Midwifery. 1991;36(6):366-72.

4. Allen DR. Managing motherhood, managing risk: fertility and danger in west central Tanzania. Ann Arbor: University of Michigan Press; 2002.

5. Byford J. Dealing with death beginning with birth: women's health and childbirth on Misima island, Papua new Guinea [PhD thesis]. Canberra: Australian National University; 1999.

6. Iskandar M, Atom B, Hull T, Dharmaputra N, Azwar Y. Unraveling the mysteries of maternal death in west Java: reexamining the witnesses. Depok: University of Indonesia, Research Institute, Center for Health Research; 1996.

7. Daviss BA. Heeding warnings from the Canary, the Whale, and the Inuit: a framework for analyzing competing types of knowledge about birth. In: Davis-Floyd R, Sargent C, editors. Childbirth and authoritative knowledge: crosscultural perspectives. Berkeley: University of California Press; 1997. p. 441-73.

8. Graham S. Traditional birth attendants in Karimoja, Uganda [PhD thesis]. London: South Bank University; 1999.

9. Davis-Floyd RE. Global issues in midwifery: mutual accommodation or biomedical hegemony? Midwifery Today Int Midwife. 2000;(53):12-16,68-9.

10. Davis-Floyd RE. La partera profesional: articulating identity and cultural space for a new kind of midwife in Mexico. Med Anthropol. 2001;20(2/3):185-244.

11. Whittaker A. Birth and the postpartum in northeast Thailand: contesting modernity and tradition. Med Anthropol. 1999;18(3):215-42.

12. Dieteker M. Maust MG, Guëmez Piñeda M, Davis-Floyd R. The construction of urban midwife identities in popular neighborhoods in Mexico City. In: Dieteker M. Maust MG, Guëmez Piñeda M, Davis-Floyd R, editors. Midwives in Mexico: continuity, controversy, and change. Austin: University of Texas Press; 2002.
13. Sieglin V. The integration of traditional midwives into the state health care system: a case study in northeastern Mexico. In: Maust MG, Gëmez Piñeda M, DavisFloyd, editors. Midwives in Mexico: continuity, controversy, and change. Austin: University of Texas Press; 2002

14. Geurts K. Childbirth and pragmatic midwifery in rural Ghana. Med Athropol. 2001;20(4):379-408.

15. Jenkins $G$. Changing roles and identities of midwives in rural Costa Rica. Med Anthropol. 2001; 20(4):409-44.

16. Davis-Floyd RE, Cosminsky S, Pigg SL, editors. Daughters of time: the shifting identities of contemporary midwives. Austin: University of Texas Press; 2001.

17. Davis-Floyd RE. Home-birth emergencies in the US and Mexico: the trouble with transport. Soc Sci Med. 2003;56(9):1911-31.

18. Matsuoka E. The postmodern midwife in Japan. Med Athropol. 2001;20(2/3):141-84.

19. DeVries R. Midwifery in the Netherlands: vestige or vanguard? Med Anthropol. 2001;20(4):277-312.

20. DeVries R. A Pleasing birth: midwives and maternity care in the Netherlands. Philadelphia: Temple University Press; 2004.

21. Cosminsky S. Childbirth and midwifery on a Guatemalan Finca. Med Anthropol. 1977;6(3):69-104.

22. Cosminsky S. Traditional midwifery and contraception. In: Bannerman R, Burton J, Ch'en Wen-Chieh, editors. Traditional medicine and health care coverage. Geneva: World Health Organization; 1983. p. 143-62.

23. Pigg SL. Authority in translation: finding, knowing, naming, and training "traditional birth attendants" in Nepal. In: Davis-Floyd R, Sargent C, editors. Childbirth and authoritative knowledge: cross-cultural perspectives. Berkeley: University of California Press; 1997. p. 233-62. 